Вісник ЛНУ імені Тараса Шевченка № 7 (330), 2019

УДК 81'243:81'25

doi : 10.12958/2227-2844-2019-7(330)-122-130

Demchenko N. O.,

$\mathrm{PhD}$, Candidate of Pedagogical Sciences, Associate Professor,

Associate Professor at the Department of Theory and Practice of Translation of Luhansk Taras Shevchenko National University,

Starobilsk - Poltava, Ukraine

ndzhd.demchenko@gmail.com

https://orcid.org/0000-0001-5158-2328

\title{
TRAINING COURSE FOR STUDENTS PHILOLOGISTS SCIENTIFIC WRIGHTING SKILLS DEVELOPMENT
}

The article focuses on the methodology of a course in academic writing and translation for philologists. It is difficult to overestimate the role of translation and translator in modern world: increasing number of international contacts in different areas and activities of international correspondence, cultural and scientific links as well as sharply increased volume of international trade and diplomatic relations. Cultural ties between peoples have expanded, and international tourism has become massive. It is clear that such rapprochement of peoples would not have been possible without translation and translators who act as intermediaries between people speaking different languages. It should be mentioned that generally recognized language of international communication in the scientific and educational community is English. Modern conditions require people engaged in intellectual work to know any foreign language, as intensive scientific and other contacts imply direct both oral and written communication of communicants. Obviously, it needs to be trained. The analysis of the scientific and methodological literature has shown that the issue of teaching translation as a whole and teaching academic writing in particular has traditionally been of considerable interest. Among the specialists who created the school of translation should be called L. Barkhudarov， V. Komissarov， L. Latyshev， Ya. Retsker， R. MinyarBeloruchev, I. Korunets, V. Karaban and many others. Among foreign experts it can be named S. Campbell, J. C. Catford, J. Munday, E. Nida, H. C. Barik, A. I. Bartolomé, G. Cabrera, R. Chriss, Y. Gambier, D. A. Garretson, I. Garcia, who have made an undoubted contribution to the development of translation studies.

The primary aim of this paper is to discuss modern concept of teaching academic writing skills and the formation of professional translation competence in the training of specialists in higher education. The author will rely primarily on reviewing the already existing body of literature. The article presents theoretically justified requirements for the teaching academic writing of linguistic students. This information can be helpful for the organization of work with the students whose specialty is translation. 


\section{Вісник ЛНУ імені Тараса Шевченка № 7 (330), 2019}

The changed world put forward new requirements for foreign language proficiency as it is becoming more open and globalized. The last decade has created a need for many people to master a foreign language, regardless of what they do. Most important part of scientific publications is published in English. Each article published in journals should be accompanied by an annotation and keywords in English. Experience has shown that one of the main problems is not so much related to the fact that it is necessary to write in a non-native language, and how correctly and logically in accordance with the norms of the international scientific community to write scientific articles in general. Back in the early 1970s, Paul Orgölen, one of Canadian most prominent researchers in the field of history and translation theory, wrote: "The task of the translator is to transfer the text from one language to another, trying to transmit as accurately as possible the message it contains. But since in order to translate well, one must first understand correctly and since an interpreter cannot be required to be a walking encyclopedia, the profession of an interpreter, like many others, involves some specialization. Therefore, there are art translators, technical, legal, advertising translators, etc." ( Garbovsky, 2004, p. 161). The importance of studying the language of the specialty, however, is productive and learning professionals in translation skills, both interpretation and translation. At the same time, taking into account the experience of Canadian colleagues, specialization in training of interpreters for professional activities walking to lead "not only by thematic approach, but also by types translation activities and in which direction translation is under way" (Garbovsky, 2004, p. 163) Since philologists first need to submit the results of their research in writing the course should be based on the development of translation techniques. There are long and successful courses of study in the scientific writing for mathematicians and physicists, biologists and chemists, and there is a need to create a special course of written scientific speech for scientists-philologists, which will include training in the writing of scientific articles in English in accordance with international requirements. The basis of the course is the formation of an academic vocabulary for the students, the study of speech characteristics of modern scientific discourse, the development of academic writing skills. Thus, the main purpose of the course of scientific writing and translation for philologists is to develop the ability to write scientific works in English (from the translation of the title and keywords to the writing of articles in English). To achieve this goal, the following objectives must be achieved:

- development of skills to work with academic English language texts;

- study of requirements of academic writing, basic principles and rules of its functioning;

- study of functional and semantic connections in academic letter;

- essay writing training: text stylistics, text structure, development of critical thinking and reasoning skills;

- study of professional vocabulary; 


\section{Вісник ЛНУ імені Тараса Шевченка № 7 (330), 2019}

- familiarity with the features of the scientific style (including its grammatical and syntax features), the structure of the scientific article and its sections;

- familiarity with the basic requirements for scientific articles by foreign publishers.

The course should be designed for the initial level of students (C1) according to the Pan-European Scale of Foreign Language Proficiency Levels (Common European Framework of Reference for Languages (CEFR)). In order to create this training course, it is necessary to determine which types of articles have been adopted by the international scientific community.

We have to mention the fact that there are so-called two types of scientific articles: primary and secondary ones. The primary scientific article is considered an article describing original study and published in peer-reviewed scientific journal, where it can be published only once. The concept of "valid/primary scientific publication/literature" was gradually issued. It can be translated as a reliable, correct, fit, primary, legitimate or mainstream scientific publication. Secondary scientific literature includes review papers, which are also published in peer-reviewed journals. The review articles are devoted to the analysis of previously published articles related to general topics. There are journals that publish only overview articles. They are intended for generalization, summation, the analysis, assessment and synthesis of earlier published information in primary publications. It was a mistake to believe that the review articles contained nothing new. On the contrary new theories can be formulated, new ideas or even paradigm is put forward and they are very much referred to in other articles.

Traditionally, the structure of scientific work contains the following components: introduction, main part, conclusions, list of used literature, and list of conditional abbreviations, list of sources used and application. A scientific article is one of the main types of scientific work. It contains a presentation of the intermediate or final results of the scientific study, covers a specific separate question on the topic of the study, records the scientific priority of the author, and makes scientific materials available to specialists. Scientific article is presented in edited and completed form. If the scientific text is poorly written even a well-conducted research might be prevent from publication. If the article has not been accepted for publication among other reasons influences the refusal may be mentioned non-authentic English used by the author. Correct grammatical forms and term and clichés usage significantly affected the quality of the proposed article. The necessary requirements are published in several numbers of journals to help authors to formalize the scientific study in accordance with these requirements. At present, the contribution of individual scientists, organizations and even entire countries to the development of science is estimated, among other things, by the number and citation of scientific publications.

Modern scientific publications are characterized by some features. Most journal articles on original research are written according to a certain format and consist of the following sections: title, abstract introduction, 


\section{Вісник ЛНУ імені Тараса Шевченка № 7 (330), 2019}

materials and methods (theoretical basis), results, discussion, acknowledgements, references. This format is abbreviated IMRAD (Introduction, Methods, Results, and Discussion). Sometimes the letter A, which stands for Abstract, is added to the acronym IMRAD, and an AIMRAD is obtained. The internal structure of the sections of the scientific article will be discussed in more detail below. If the article is devoted to theoretical problems the methods section is replaced by theoretic basis. The text of the publications contains complete references to other scientific works, so that the reader can find the work referred to (references, citations) on his own. The publications use illustrations that are described in the text (tables, charts, schematic, diagrams, graphs, line-drawings, images). There is a detailed description of how the results were obtained and how the author(s) came to the conclusions of the publication (methods, materials). Publications in peerreviewed journals are the most valuable. In such a journal, manuscripts of articles are published only after being critically reviewed and approved by at least two specialists (reviewers). The publication is constantly publicly available to all readers without any restrictions (permanent availability for public).

Practical training assumes:

- study of academic vocabulary, speech patterns, characteristic of English-language scientific discourse;

- development of academic writing skills;

- development of educational cognitive skills.

Independent work of trainees consists of:

- planning and evaluation of their educational activities based on individual educational characteristics;

- performing written tasks, including writing works required in the course. (writing annotations, theses, scientific article, etc.).

An approximate course outline can be like that:

a) introductory lesson: familiarity with the goals and objectives of the course recommended by literature, dictionary bases, the concept of copyright, the index of scientific citation and bibliography.

b) content of classes

c) familiarization with some dictionaries

All modern dictionaries have electronic versions. They exist in both off-line $\mathrm{CD}$ versions and on-line mode.

Some exercises can demonstrate the training process. For example: Look at the following extracts from the beginning of books and record the bibliographic details: author, date, title, edition, place of publication in the table below.

Next level of training can be devoted to the analysis of bibliographic data and the title of the scientific article: narrow (specific title) and wide (general title) title.

Content of classes will include the following information:

The main requirement for the title of the article is brevity and clarity. 


\section{Вісник ЛНУ імені Тараса Шевченка № 7 (330), 2019}

The maximum length of the header is $10-12$ words. The title should be meaningful, expressive, reflect the content of the article.

When selecting the title of an article, the following general recommendations must be followed:

1. The title must be informative.

2. The title should attract the attention of the reader.

3. In the title, as in the whole article, it is necessary to strictly adhere to the scientific style of speech.

4. It should clearly reflect the main topic of the study and not mislead the reader about the issues addressed in the article.

5. The title should include some of the keywords reflecting the substance of the article. It is desirable that they stand at the beginning of the headline.

6. Only common abbreviations can be used in the header.

7. When translating the title of an article into English the types of exercise can be: titles).

Examine the following "broad" titles (Study the following general

Examine the following "narrow" titles (Study the following specific titles).

Title this article (Entity the article).

( Examples of tasks are borrowed from the manual by A.MinyarBelorucheva (Minyar-Belorucheva, 2011, p.7 - 9). Familiarity with requirements to scientific article, MRAD-format, formation of practical skills of writing annotation, outline of article, keywords.

Content of classes MRAD-format is based on a very simple logic. The sections of the article are kind of answer natural questions. The first question is "What is the problem of the study?" The answer should be contained in the Introduction. The next question is "How was the problem studied?" This question is answered in the Methods section. "What are the main findings or even discoveries?" Look for a response in the Results section. "What do the results mean?" The answer is in the Discussion section. In addition, any article begins with a title, followed by a list of authors, their place of work and address, the place where the study is to be submitted. Then follows Abstract, Summary, Resume, which is a very brief statement of the content of the article and at the end of which you can find keywords (key words). After the Abstract, the article itself begins (paper body). Most often at the end of the article, after the Discussion section, Thanks are placed (How to write and publish an article in an international scientific journal: methodological recommendations, 2011, p. 23).

Types of exercises:

- Study the following model essay.

- Write a key sentence for each of the following topics.

- Find topic and supporting ideas in the following sentences.

- Rewrite the following "weak" paragraph by answering the questions and using those answers within the paragraph. 


\section{Вісник ЛНУ імені Тараса Шевченка № 7 (330), 2019}

(Examples of tasks are borrowed from the manual by A. MinyarBelorucheva (Minyar-Belorucheva, 2011, page 51-83).

In summary, it should be noted that the course of special writing and translation is certainly necessary for scientists-philologists who want to introduce the results of their research to the world scientific community. This article reflects only the first Course development phase, it is planned to be continued and tested ESP course for philologists in Luhansk national university, at foreign languages department.

\section{Список використаної літератури}

1. Гарбовский Н. К. Теория перевода: учебник. М.: Изд-во Моск. ун-та, 2004. 544 с. 2. Как написать и опубликовать статью в международном научном журнале: метод. рекомендации / сост. И. В. Свидерская, В. А. Кратасюк. Красноярск: Сиб. федерал. ун-т, 2011. 52 с. 3. Миньяр-Белоручева А. П. Учимся писать по-английски: письменная научная речь: учебное пособие. М.: Флинта: Наука, 2011. 128 с. 4. Комиссаров В. Н. Теоретические основы методики обучения переводу. Москва: Рема, 1997. 112 с. 5. Миньяр-Белоручев Р. К. Общая теория перевода и устный перевод. М.: Воениздат, 1980. 237 с. 6. Hall K. R. Cognition and translation didactics. Meta. Translators Journal. 1996. Vol. 41. P. 114-117.

\section{References}

1. Garbovskij, N. K. (2004). Teoriya perevoda [Theory of Translation]. M.: Izd-vo Mosk. un-ta [in Russian]. 2. Sviderskaya, I. V. \& Kratasyuk V. A. (Eds.). (2011). Kak napisat' i opublikovat' stat'yu v mezhdunarodnom nauchnom zhurnale [How to write and publish an article in an international scientific journal]. Krasnoyarsk: Sib. federal. un-t [in Russian]. 3. Min'yar-Belorucheva, A. P. (2011). Uchimsya pisat' poanglijski: pis'mennaya nauchnaya rech' [Learn to write in English: written scientific speech]. M.: Flinta: Nauka [in Russian]. 4. Komissarov, V. N. (1997). Teoreticheskie osnovy metodiki obucheniya perevodu [The theoretical basis of teaching translation]. M.: Rema [in Russian]. 5. Min'yarBeloruchev, R. K. (1980). Obshchaya teoriya perevoda i ustnyj perevod [General theory of translation and interpretation]. M.: Voenizdat [in Russian]. 6. Hall, K. R. (1996). Cognition and translation didactics. Meta. Translators Journal, 41, 114-117.

\footnotetext{
Демченко Н.О. Курс для навчання розвитку навичок наукового письмового мовлення студентів філологів

Статтю присвячено проблемі навчання наукової писемного мовлення. Аналізуються можливості створення i апробація курсу, спрямованого на вирішення цього завдання. Проаналізовано досвід зарубіжних колег, які вирішують цю проблему. Число міжнародних контактів зростає дуже швидко, різко збільшується обсяг інформації, якою обмінюються люди.
} 


\section{Вісник ЛНУ імені Тараса Шевченка № 7 (330), 2019}

Обмін інформацією відбувається як в усній формі мови, так і в письмовій. При обміні науковою інформацією це відбувається здебільшого в письмовій формі. Така форма спілкування вимагає володіння певними лінгвістичними навичками письмовій мови. Она має свої особливості. Загальновизнаною мовою міжнародного спілкування в науково-освітньому співтоваристві $\epsilon$ англійська. Вчені обмінюються результатами своїх досліджень, публікуючи їх у вигляді статей, тез, дисертаційних робіт, монографій. Як показує досвід, головні проблеми пов'язані не стільки 3 тим, що доводиться писати нерідною мовою, а 3 тим, як правильно і логічно відповідно до норм міжнародного наукового співтовариства писати наукові статті. Незаперечна важливість вивчення професійної мови галузі, однак, продуктивним $є$ i навчання фахівців навичкам перекладу, як усного, так і письмового. Оскільки вченимфілологам в першу чергу необхідно представляти результати своїх досліджень в письмовій формі, то і створюваний курс буде заснований на відпрацюванні прийомів письмового перекладу, який буде включати в себе навчання написання наукових статей англійською мовою відповідно до міжнародних вимог. Основу курсу становить формування в учнів академічного вокабуляра, вивчення речевих оборотів, характерних для сучасного наукового дискурсу, розвиток умінь академічного письма. Основна мета навчального курсу наукового письма та письмового перекладу для філологів - розвинути вміння писати наукові роботи англійською мовою (починаючи 3 перекладу назви і ключових слів і закінчуючи написанням статей на англійській мові). В результаті проведеного аналізу було розроблено пробний курс, для навчання письмової наукової мови студентів філологів, який вимагає практичної апробації і подальшого вдосконалення для широкого впровадження в процес навчання.

Ключові слова: теорія перекладу, англійська мова для спеціальних цілей, англійська для наукових цілей, методика навчання письмової наукової мови, науковий дискурс, наукова стаття.

Демченко Н. А. Курс для обучения развития навыков научной письменной речи студентов филологов

Статья посвящена проблеме обучения научной письменной речи. Анализируются возможности создания и апробация курса, направленного на решение этой задачи. Проанализирован опыт зарубежных коллег, решающих эту проблему. Число международных контактов растет очень быстро, резко увеличивается объем информации, которой обмениваются люди. Обмен информации происходит как в устной форме речи, так и в письменной. При обмене научной информацией в основном это происходит в письменной форм. Такое общение требует владения определенными лингвистическими навыками письменной речи. Она имеет свои особенности. Общепризнанным языком международного общения в научно-образовательном сообществе является английский. Ученые обмениваются результатами своих 


\section{Вісник ЛНУ імені Тараса Шевченка № 7 (330), 2019}

исследований, публикуя их в виде статей, тезисов, диссертационных работ, монографий. Как показывает опыт, главные проблемы связаны не столько с тем, что приходиться писать на неродном языке, а с тем, как правильно и логично в соответствии с нормами международного научного сообщества писать научные статьи. Неоспорима важность изучения подъязыка специальности, однако, продуктивным является и обучение профессионалов навыкам перевода, как устного, так и письменного. Поскольку учёным-филологам в первую очередь необходимо представлять результаты своих исследований в письменной форме, то и создаваемый курс будет основан на отработке приёмов письменного перевода, который будет включать в себя обучение написанию научных статей на английском языке в соответствии с международными требованиями. Основу курса составляет формирование у обучаемых академического вокабуляра, изучение речевых оборотов, характерных для современного научного дискурса, развитие умений академического письма. Основная цель учебного курса научного письма и письменного перевода для филологов - развить умение писать научные работы на английском языке (начиная с перевода названия и ключевых слов и заканчивая написанием статей на английском языке). В результате проведенного анализа был разработан пробный курс, для обучения письменной научной речи студентов филологов, который требует практической апробации и дальнейшего совершенствования для широкого внедрения в процесс обучения филологов.

Ключевые слова: теория перевода, английский язык для специальных целей, английский для научных целей, методика обучения письменной научной речи, научный дискурс, научная статья.

\section{Demchenko N. O. Training Course for Students Philologists Scientific Writing Skills Development}

The article is devoted to the problem of teaching scientific written speech. The possibilities of creating and testing a course aimed at this task are analyzed. The experience of foreign colleagues solving this problem has been analyzed. The number of international contacts is growing very rapidly, and the volume of information exchanged by people is increasing dramatically. The exchange of information takes place both orally and in writing form. The exchange of scientific information is mainly done in a written form. This form of communication requires the possession of certain linguistic skills as it has its own features. Generally recognized language of international communication in the scientific and educational community is English. Scientists exchange the results of their research, publishing them in the form of articles, theses, dissertation works and monographs. A large and most important part of scientific publications is published in English. Experience has shown that the main problems are not so much related to the fact that it is necessary to write in non-native language, but to be able to express the ideas correctly and logically in accordance with the norms of the international scientific community. However, training professionals in translation skills, 


\section{Вісник ЛНУ імені Тараса Шевченка № 7 (330), 2019}

both oral and written, is also productive. At the same time, specialization in preparation for professional activities of translators should be carried out not only in the sphere of English for special purposes, English for academic purposes, but also by types of translation activities. Since philologists are primarily required to submit the results of their research in writing, the course will be based on the development of translation techniques, which will include teaching to write scientific articles in English in accordance with international requirements. The basis of the course is the formation of an academic vocabulary, the study of speech patterns, characteristic of modern scientific discourse, as well as the development of academic writing skills. Thus, the main purpose of the course of scientific writing and translation for philologists is to develop the ability to write scientific works in English including the translation of the title and key words. As a result of the analysis, a trial course was developed to teach the written scientific speech of philologists students, which requires practical testing and further improvement for wide integration into the learning process.

Key words: English for special purposes, English for academic purposes, English language teaching, methodology of academic writing, scientific discourse, scientific article.

Стаття надійшла до редакції 01.10.2019 р.

Стаття прийнята до друку 14.10.2019 р.

Рецензент - д.філ.н., проф. Кобзар О. І. 